\title{
In depth analysis of the association of FTO SNP (rs9939609) with the expression of classical phenotype of PCOS: a Sri Lankan study
}

\author{
Umayal Branavan ${ }^{1 *}$ D, Sulochana Wijesundera ${ }^{2}$, Vishvanath Chandrasekaran ${ }^{3}$, Carukshi Arambepola $^{4}$ and
} Chandrika Wijeyaratne ${ }^{1}$

\begin{abstract}
Background: PCOS is a common disorder of women due to genetic, endocrine and environmental effects that manifests from puberty. The rs9939609 variant of fat mass and obesity associated (FTO) gene is linked to metabolic derangement in PCOS. We previously identified FTO (rs9939609) as a susceptibility locus for PCOS among Sri Lankan women and also explored the role of kisspeptin. Associated factors of the FTO candidate gene among South Asians with PCOS are unknown.

Methods: This study aimed to determine the association between FTO (rs9939609) polymorphism with clinical (BMI, acanthosis nigricans, hirsutism) and biochemical (serum kisspeptin and testosterone levels) characteristics of PCOS in a cohort of Sri Lankan women. Genetic and clinical data including serum kisspeptin and testosterone concentrations of our previously reported cases $(n=55)$ and controls $(n=110)$ were re-analyzed, specifically for an association with rs9939609 variant of FTO gene.

Results: Logistic regression analysis ( $A A-O R=5.7,95 \% C l=2.41-13.63, p<0.05)$ and genetic inheritance analysis ( $A A-O R=5.49,95 \% \mathrm{Cl}=2.34-12.88, p<0.05$ ) showed that FTO (rs9939609) polymorphism is significantly associated with PCOS and its metabolic manifestations. Serum testosterone was significantly higher in affected women with mutant genotypes (AA+AT) than with the normal allele $(T T)(p<0.05)$. Although serum kisspeptin was higher in subjects with PCOS and mutant alleles than controls, this difference was not significant $(p>0.05)$.

Conclusion: FTO gene variant rs9939609 is associated with hyperandrogenemia and metabolic manifestations of PCOS among women of Sri Lankan descent with the well-characterized phenotype. Serum kisspeptin and the FTO genotypes lack a significant association when adjusted for confounders.
\end{abstract}

Keywords: Polycystic ovary syndrome (PCOS), FTO SNP rs9939609, Sri Lankan

\section{Background}

Polycystic ovary syndrome is the commonest hormonal derangement among young women, from early reproductive years [1]. The well characterized phenotype of PCOS is commonly associated with insulin resistance, obesity and future metabolic/cardiovascular outcomes such as diabetes mellitus, hypertension, carotid artery intimal thickening,

\footnotetext{
* Correspondence: umayal13lk@gmail.com

'Department of Obstetrics and Gynecology, Faculty of Medicine, University

of Colombo, PO Box 271, Kynsey Road, Colombo 08, Sri Lanka

Full list of author information is available at the end of the article
}

and pregnancy related metabolic risks [2-6]. South Asians have a greater expression of the metabolic manifestations of PCOS, occurring from a younger age and with a greater degree of insulin resistance, linked to central adiposity, as opposed to white Caucasians with the condition [2].

The etiology of PCOS is undetermined. It is viewed as a complex trait due to heritable and environmental factors [7-9]. In 2007, genome-wide association study identified the fat mass and obesity-associated (FTO) gene as an obesity susceptibility gene [10]. The human FTO gene is located on chromosome 16 and expressed in a

(c) The Author(s). 2020 Open Access This article is distributed under the terms of the Creative Commons Attribution 4.0 International License (http://creativecommons.org/licenses/by/4.0/), which permits unrestricted use, distribution, and reproduction in any medium, provided you give appropriate credit to the original author(s) and the source, provide a link to the Creative Commons license, and indicate if changes were made. The Creative Commons Public Domain Dedication waiver (http://creativecommons.org/publicdomain/zero/1.0/) applies to the data made available in this article, unless otherwise stated. 
wide range of tissues, including adipose tissue and specific areas of brain and muscles, suggesting its potential role in body weight regulation [11]. Several single nucleotide polymorphisms (SNPs) of the FTO gene have been described. The variant FTO rs9939609 is the most extensively studied, located within the first FTO intron which has two alleles, $\mathrm{A}$ and $\mathrm{T}$, the former linked to an increased risk for both obesity and type 2 diabetes mellitus [12].

The hypothalamic pituitary gonadal (HPG) axis plays a central role in reproduction. Important regulators of puberty include kisspeptin, a peptide product of Kiss1 gene, and its receptor GPR54 [13]. Activation of GnRH neurons is critical for the onset of puberty [14]. GPR54 receptor being located on neurons that secrete $\mathrm{GnRH}$ implies an important role for kisspeptin/GPR54 signaling in reproduction $[15,16]$.

The FTO gene affects adiposity, insulin resistance and the development of type 2 diabetes mellitus. Obesity and PCOS are closely related [17, 18]. The FTO gene variants have been demonstrated to be a key risk for PCOS $[5,19-21]$. Since PCOS, in its well characterized form, often begins from adolescence, especially among South Asians [22], it is reasonable to hypothesize that FTO rs9939609 polymorphism influences the Kiss1/kisspeptin/GPR54 pathway in PCOS. Furthermore, while FTO variants are linked to insulin resistance and glucose intolerance in PCOS [23], there is paucity of literature on the relationship between FTO variants and hyperandrogenaemia [11, 24].

We aimed to identify any association of FTO gene variant rs9939609 with clinical (metabolic and hyperandrogenic) and hormonal (serum kisspeptin and testosterone) characteristics of PCOS among young Sri Lankan women with well characterized PCOS.

\section{Methods}

This study was carried out at the Endocrine Clinic of the University Unit, Colombo, Sri Lanka, during the period from 1st January 2016 to 31st December 2016. Ethical approval for this study was obtained from the Ethics Review Committee, Faculty of Medicine, University of Colombo.

Diagnosis of PCOS was based on the Rotterdam criteria [25]. Details of sample size calculation [26], inclusion and exclusion criteria of study subjects and control group are described in previous reports [27-29] are given below:

\section{Sample size calculation}

The sample size was calculated based on Schlesselman case control study formula [26];

$$
\mathrm{n}=\frac{\left(z_{\alpha} \sqrt{2 \overline{p q}}+z_{\beta} \sqrt{p_{1} q_{1}+p_{0} q_{0}}\right)^{2}}{\left(p_{1}-p_{0}\right)^{2}}
$$

The exposure rate of allele frequency of SNPs among controls (30-44\%) was based on literature from other countries as no studies have been done in Sri Lanka [10, $30-32]$. The estimated proportion of $38 \%$ was used in sample size calculation.

The OR used in this study was 2.7; because Sri Lankans with anovulatory PCOS manifest severe symptoms at a younger age, with greater IR and a higher prevalence of metabolic syndrome than white Europeans [2].

P1 = Proportion of exposure among cases was calculated using the following formula;

$$
p_{1}=\frac{p_{0} R}{\left[1+p_{0}(R-1)\right]} .
$$

The total number of cases recruited for this study was 55 and by selecting double the number of controls per cases, the final total number of controls was 110. Thus, in total 165 subjects were included in this study.

\section{Recruitment of subjects Inclusion criteria}

Adolescent women whose symptoms manifested between 11 and 19 years of age (WHO) with all 3 diagnostic criteria present between 16 and 19 years of age [33] were recruited for this study. The lower age limit for inclusion was 15 years, since the mean age of menarche reported among Sri Lankan girls is 13.54 years (standard deviation, 0.86 ) and 2 years after menarche was required to exclude the period of menstrual irregularity that usually follows menarche [34].

Women with all 3 following diagnostic criteria were recruited as cases: oligomenorrhoea/oligo-ovulation, clinical or biochemical hyperandrogenism and polycystic ovaries on ultrasound. Details of diagnostic criteria were described briefly in our previous studies [27-29].

Women excluded from the study were those with inherited disorders of IR such as Rabson -Mendenhall syndrome, Cushing syndrome, hyperprolactinaemia, untreated hypothyroidism, congenital adrenal hyperplasia or with an androgen secreting ovarian/adrenal tumour and those taking corticosteroid, antiepileptic or antipsychotic drugs or hormonal contraception and those currently pregnant or in the first postpartum year.

\section{Control sample}

Working women of reproductive age from similar ethnic and social background as the affected subjects were approached. Consenting, asymptomatic, normo-androgenic and normal cycling since adolescence women in whom 
PCOS was objectively excluded by clinical, biochemical and ultrasound assessment, were recruited as controls.

\section{Clinical and biochemical evaluation}

Socio demographic, reproductive information (menstruation, fertility), age and degree of severity of clinical feature of PCOS, drug history, family history of diabetes, anthropometry (BMI and central obesity), resting blood pressure, hyperandrogensim assessed by a single clinical observer that includes hirsutism (modified FG score), temporal hair loss, acne, acanthosis nigricans, ovarian ultrasound, serum kisspeptin and testosterone concentrations of all subjects were utilized from our previously reported studies [27-29].

\section{Statistical analysis}

Statistical analysis was carried out with previously reported SNPs of the obesity gene (FTO), selected candidate genes of HPG axis (Kiss1, GPR54, GnRH, FSHB, FSHR, LHB, LHCGR) and insulin receptor gene (INSR) $[28,29]$ and serum kisspeptin and testosterone concentration [27].

The Kolmogorov-Smirnov test was used to test the normality of distribution. Values with a biological distribution are presented as mean \pm standard error for mean. Comparison of means between cases (those with PCOS) and controls (those without PCOS) was performed with independent sample $t$ test. Chi-square test was used for comparison of genotype frequency between groups. It was also used for describing the correlation of genetic alleles with other numeric variables. To assess the magnitude of the risk factors in the development of PCOS, first all cases and controls were compared using crude odds ratio (OR) and 95\% confidence interval (CI) by binary logistic regression (forward LR) method. Factors assessed were: BMI, serum kisspeptin and testosterone concentration with the obesity gene - FTO (rs9939609), HPG axis genes - Kiss1 SNPs (rs5780218, rs4889), GPR54 SNPs (rs10407968, rs125 07294, rs350131, chr19:918686, chr19:918735), GnRH (rs61 85), FSHB (rs6169), FSHR (rs6165/rs6166) and LHCGR (rs2293275) and insulin receptor gene (rs1799817), all of which were included to the logistic regression analysis in order to identify risk factors for PCOS. To assess the risk for PCOS associated with the FTO rs 9939609 polymorphism after controlling for confounders, logistic regression analysis was performed using forward LR method to obtain adjusted OR. In the regression model, case control status was included as the dependent variable; and the main predictor (FTO rs9939609 polymorphism was categorized as AA [homozygous], AT [heterozygous] and TT [wild type]) along with confounders (all significant factors in the univariate analysis) as independent variables. To determine the risk for FTO rs9939609 polymorphism to be associated with BMI, mFG scale, serum testosterone and kisspeptin levels, forward LR was performed. This analysis categorized the FTO rs9939609 into 2 groups - mutant allele (AA and
AT) and normal allele (TT) and included them as the dependent variable. Any interaction of FTO rs9939609 polymorphism with each variable was analyzed individually to test for significance. Variables found to have a significant interaction were then included to the model. Several regression models were developed for both analysis, and the best model was selected based on the goodness of fit. All analyses were performed by SPSS software (v.18.0 SPSS, Inc., Chicago, IL). The level of significance was set as $5 \%$.

Deviations from the Hardy-Weinberg equilibrium were tested by comparison of observed and expected genotype frequencies with $\chi^{2}$ test. Calculation of genotype and haplotype associations for all the SNPs was carried out using SNPSTATS program (http://bioinfo. iconcologia.net/index.php?module=Snpstats). Five inheritance models (co-dominant, dominant, recessive, overdominant and additive) were applied for statistical analysis. The best inheritance model was assessed using the Akaike information criteria (AIC) and the Bayesian information criteria (BIC) and the model with the lowest values considered the best fit.

\section{Results}

\section{Risk factors for PCOS development}

Results of demographic, clinical and biochemical parameters of study subjects are explained in our previous study and Table 1 summarize the major results of our previous study. Table 2 shows the association of cases of PCOS and controls based on the univariate and logistic regression analysis. PCOS is associated with BMI, serum testosterone and kisspeptin concentrations and the FTO rs9939609 polymorphism by univariate analysis. Our model showed that BMI, serum kisspeptin levels and FTO rs9939609 (AA) polymorphism remained significant after adjusting for potential confounders. The model was statistically significant with a Hosmer and Lemeshow test value of $0.34(p>0.1$ taken as significant). The model also explained 24\% (Nagelkerke R2) of

Table 1 Demographic, clinical and biochemical characteristics of the study population (results from our previous study Branavan U et al. [28], Plos one)

\begin{tabular}{llll}
\hline & PCOS $(n=55)$ & CONTROLS $(n=110)$ & $p$ \\
\hline Age $($ Years $)$ & $24.67 \pm 0.883$ & $33.80 \pm 0.528$ & 0.061 \\
BMI $\left(\mathrm{Kg} / \mathrm{m}^{2}\right)$ & $26.89 \pm 0.716$ & $25.25 \pm 0.344$ & 0.007 \\
mFG score & $8 \pm 0.445$ & $3 \pm 0.222$ & 0.006 \\
WC:HC & $0.839 \pm 0.008$ & $0.824 \pm 0.004$ & 0.114 \\
FBG $(\mathrm{mg} / \mathrm{dL})$ & $98.81 \pm 2.08$ & $108.69 \pm 2.74$ & 0.284 \\
Kisspeptin $(\mathrm{nmol} / \mathrm{L})$ & $4.873 \pm 0.238$ & $4.127 \pm 0.132$ & 0.033 \\
Testosterone $(\mathrm{nmol} / \mathrm{L})$ & $4.713 \pm 0.458$ & $3.415 \pm 0.256$ & 0.018 \\
\hline
\end{tabular}

BMI Body mass index, $m F G$ modified Ferriman-Gallway score, WC:HC waist circumference: hip circumference, FBG fasting blood glucose, TSH Thyroid stimulating hormone, FSH Follicle stimulating hormone, $\mathrm{LH}$ Luteinizing hormone 
Table 2 Risk factors for PCOS

\begin{tabular}{llllll}
\hline Risk factor & Genotype & Cases $N=55$ & Controls $N=110$ & Crude OR (95\% Cl) & Adjusted OR (95\%Cl) Model $^{a}$ \\
\hline BMI (mean, SE) & - & $26.89 \pm 0.72$ & $25.25 \pm 0.34$ & $1.1(1.01-1.18)$ & $1.1(1.01-1.2)$ \\
Serum testosterone (mean, SE) & - & $4.713 \pm 0.46$ & $3.415 \pm 0.26$ & $1.2(1.03-1.29)$ & \\
Serum kisspeptin (mean, SD) & - & $4.873 \pm 0.24$ & $4.127 \pm 0.13$ & $1.37(1.1-1.71)$ & $1.4(1.14-1.85)$ \\
FTO (rs9939609) & AA & $22(40 \%)$ & $15(13.6 \%)$ & $4.9(2.16-11.0)$ & $5.7(2.41-13.63)$ \\
(No, \%) & AT & $13(23.6 \%)$ & $23(20.9 \%)$ & $2.0(0.86-4.65)$ & $2.2(0.9-5.35)$ \\
& $T^{R}$ & $20(36.3 \%)$ & $72(65.4 \%)$ & 1 &
\end{tabular}

${ }^{a}$ Logistic Regression (LR) model showing adjusted odds ratio (OR) of factors significant for PCOS

Logistic regression analysis was carried out for all the SNPs of Kiss1, GPR54, GnRH, FSHB, FSHR, LHCGR, INSR and FTO along with hormonal (kisspeptin and

testosterone levels) characteristics. Only the variables with significant association are shown in the table

the variance among those with PCOS and correctly classified $72 \%$ of the cases, which confirms a good fit. Meanwhile, this model demonstrated there was no significant association between genes of the HPG axis (Kiss1, GPR54, GnRH, FSHB, FSHR, LHCGR) and insulin receptor gene (INSR) with PCOS.

\section{Hardy-Weinberg equilibrium and mode of inheritance analysis}

The genotype distributions of the FTO SNP (rs9939609) was not in the Hardy-Weinberg equilibrium in both patients and controls $(p<0.05)$.

Association between the FTO SNP (rs9939609) and PCOS risk was analyzed under five gene models (co-dominant, dominant, recessive, over-dominant and log additive).

The FTO gene rs9939609 polymorphism - under the co-dominant model, the genotypes "AA" $(\mathrm{OR}=5.49$; 95\% CI -2.34-12.88; $p<0.05)$; under the dominant model genotype "A/T-A/A" (OR $=3.21$ 95\% CI -1.62-6.37; $p<$ $0.05)$; under recessive model genotype " $\mathrm{A} / \mathrm{A}$ " $(\mathrm{OR}=4.45$, 95\% CI $-2.01-9.90 ; p<0.05)$ and the log additive model $(\mathrm{OR}=2.30 ; 95 \% \mathrm{CI}-1.51-3.51 ; p<0.05)$ were associated with increased risk for PCOS (Table 3).

The model with the lowest AIC and BIC values for a given polymorphism was considered the best-fit model.
The AIC and BIC values indicated that the log additive model may serve as the best-fit model of rs9939609 polymorphism of FTO gene (Table 3 ).

\section{Association of FTO rs9939609 polymorphism with clinical and hormonal characteristics of PCOS}

The best predictors of FTO rs9939609 polymorphism, with a statistically significant association were the $\mathrm{mFG}$ scale and serum testosterone (Table 4). Furthermore, interaction between FTO rs 9939609 polymorphism with the variables (BMI, $\mathrm{mFG}$, serum testosterone and kisspeptin levels) showed significant interaction between FTO AA genotype and mFG $(p=0.042)$; whereas the AT genotype of FTO gene showed a marginally significant interaction $(p=0.054)$ with $\mathrm{mFG}$.

\section{Association of FTO genotype with serum kisspeptin and testosterone levels}

Although kisspeptin levels were significantly associated with FTO genotype in the univariate analysis; the association was insignificant when adjusted for confounders (Table 4). Nevertheless, when the subjects were divided based on the FTO genotypes and compared with serum kisspeptin and testosterone levels, subjects with AA genotype had higher mean serum kisspeptin levels when

Table 3 Association between FTO SNP (rs9939609) and PCOS risk under multiple models of inheritance

\begin{tabular}{|c|c|c|c|c|c|c|c|}
\hline Model & Genotype & Controls & Cases & OR $(95 \% \mathrm{Cl})$ & $\mathrm{p}$ & $\mathrm{AIC}$ & $\mathrm{BIC}$ \\
\hline \multirow[t]{3}{*}{ Codominant } & $\mathrm{T} / \mathrm{T}$ & $68(65.4 \%)$ & 20 (37\%) & 1.00 & 0.00 & 192.7 & 201.8 \\
\hline & $A / T$ & $23(22.1 \%)$ & $13(24.1 \%)$ & $1.92(0.83-4.47)$ & & & \\
\hline & $\mathrm{A} / \mathrm{A}$ & $13(12.5 \%)$ & $21(38.9 \%)$ & $5.49(2.34-12.88)$ & & & \\
\hline \multirow[t]{2}{*}{ Dominant } & $T / T$ & 68 (65.4\%) & $20(37 \%)$ & 1.00 & 0.00 & 195.3 & 201.4 \\
\hline & $\mathrm{A} / \mathrm{T}-\mathrm{A} / \mathrm{A}$ & $36(34.6 \%)$ & 34 (63\%) & $3.21(1.62-6.37)$ & & & \\
\hline \multirow[t]{2}{*}{ Recessive } & $\mathrm{T} / \mathrm{T}-\mathrm{A} / \mathrm{T}$ & 91 (87.5\%) & 33 (61.1\%) & 1.00 & 0.00 & 192.9 & 199 \\
\hline & $\mathrm{A} / \mathrm{A}$ & $13(12.5 \%)$ & 21 (38.9\%) & $4.45(2.01-9.90)$ & & & \\
\hline \multirow[t]{2}{*}{ Overdominant } & $\mathrm{T} / \mathrm{T}-\mathrm{A} / \mathrm{A}$ & 81 (77.9\%) & 41 (75.9\%) & 1.00 & 0.78 & 206.9 & 213 \\
\hline & $A / T$ & $23(22.1 \%)$ & 13 (24.1\%) & $1.12(0.51-2.43)$ & & & \\
\hline Logadditive & - & - & - & $2.30(1.51-3.51)$ & 0.00 & 190.9 & 197 \\
\hline
\end{tabular}

$O R$ odds ratio, $C l$ confidence interval, AIC Akaike information criteria, BIC Bayesian information criteria 
Table 4 Association of FTO rs9939609 polymorphism with different variables (BMI, mFG score, testosterone and kisspeptin levels

\begin{tabular}{llc}
\hline Variables & Crude OR $(95 \% \mathrm{Cl})$ & Adjusted OR $(95 \% \mathrm{Cl})$ Model 1 \\
\hline BMl & $1.0(0.94-1.09)$ & $1.1(1.02-1.23)$ \\
mFG score & $1.1(1.04-1.25)$ & $1.1(1.02-1.29)$ \\
Testosterone & $1.2(1.05-1.32)$ & \\
Kisspeptin & $1.0(0.82-1.22)$ & \\
\hline
\end{tabular}

compared to AT and TT genotypes (Fig. 1) while the mean testosterone concentrations were greater in subjects with the AT genotype $(p>0.05)$ (Fig. 1). In addition, serum testosterone levels were significantly higher in subjects with mutant alleles $(\mathrm{AA}+\mathrm{AT})$ when compared to those with normal allele (TT) $(p=0.04)$.

\section{Association of FTO genotypes with body mass index (BMI)}

When the subjects were subdivided based on their BMI using the Asian cut off $\left(\mathrm{BMI}<25 \mathrm{~kg} / \mathrm{m}^{2}\right)$ and compared with the FTO genotype (Fig. 2) we found a significant correlation between FTO gene polymorphism and BMI (chi square value $=17.05, p<0.05$ ). The frequency of AA genotype was greater among obese PCOS subjects $(\mathrm{BMI} \geq 25 \mathrm{~kg} / \mathrm{m} 2)$ while the TT allele was seen in a greater proportion of controls.

\section{FTO with cutaneous markers of insulin resistance (Acanthosis nigricans)}

Acanthosis nigricans was used as a clinical marker of insulin resistance. PCOS subjects with the AA genotype had a significantly higher frequency of acanthosis nigricans when compared to those with the TT genotype $(p<0.05)$ (Fig. 3). Acanthosis was seen most commonly among women with PCOS who were obese or overweight.

\section{Discussion}

The pathogenesis of PCOS remains complex with multiple factors deemed to determine its expression. A single cause for PCOS is unlikely [35]. Overweight and obesity affects $40-80 \%$ of women with PCOS [11, 36, 37]. Genome-wide association studies reported that obesity gene FTO has an association with PCOS, mostly among Asians [38]. Nevertheless, the mechanism underlying this association of the FTO gene polymorphism with PCOS risk remains unclear. Some researchers have reported that FTO gene influences PCOS mainly via the association with obesity or obesity-related parameters such as BMI [5, 11, 39, 40]. We found that the FTO rs9939609 variant is unequivocally associated with PCOS among a cohort of well-characterized Sri Lankan women by both logistic regression analysis and genetic inheritance analysis. While many others have shown a significant association of FTO rs9939609 polymorphism with PCOS [5, 19-21]; a few have reported the lack of such an association $[11,39,41]$.

The association between insulin resistance (IR) and FTO rs9939609 polymorphism is well established. Russell et al., showed that overexpression of FTO in INS-1 pancreatic beta cells increased the first phase of insulin secretion response to glucose [42]. Interestingly, we observed that the majority of subjects with PCOS had acanthosis nigricans (a clinical marker associated with IR - thickened, velvety, relatively darker areas of skin on the neck, armpit and in skin folds [43]) and had the A allele (either AT or AA) in the FTO rs9939609 polymorphism (Fig. 3). Therefore, it is reasonable to conclude that IR is associated with FTO rs9939609 polymorphism among Sri Lankan women with well characterized PCOS.

No studies have been reported so far on a possible association between serum kisspeptin levels and the FTO gene polymorphism in PCOS. Although we found kisspeptin to be significantly associated with FTO genotype in the univariate analysis; the association became insignificant when

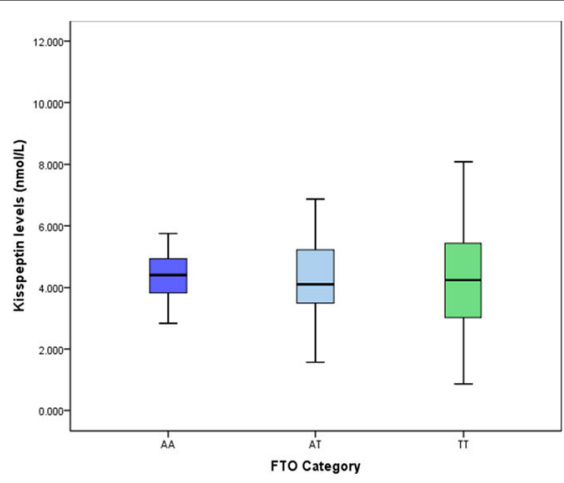

(A)

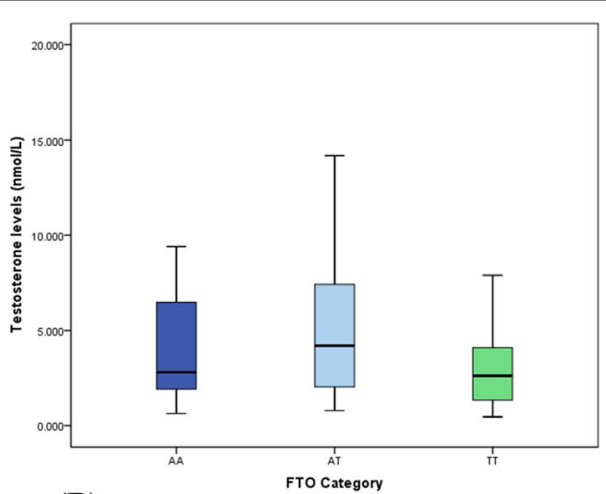

(B)

Fig. 1 Association of FTO genotypes with serum (a) kisspeptin levels and (b) testosterone levels 


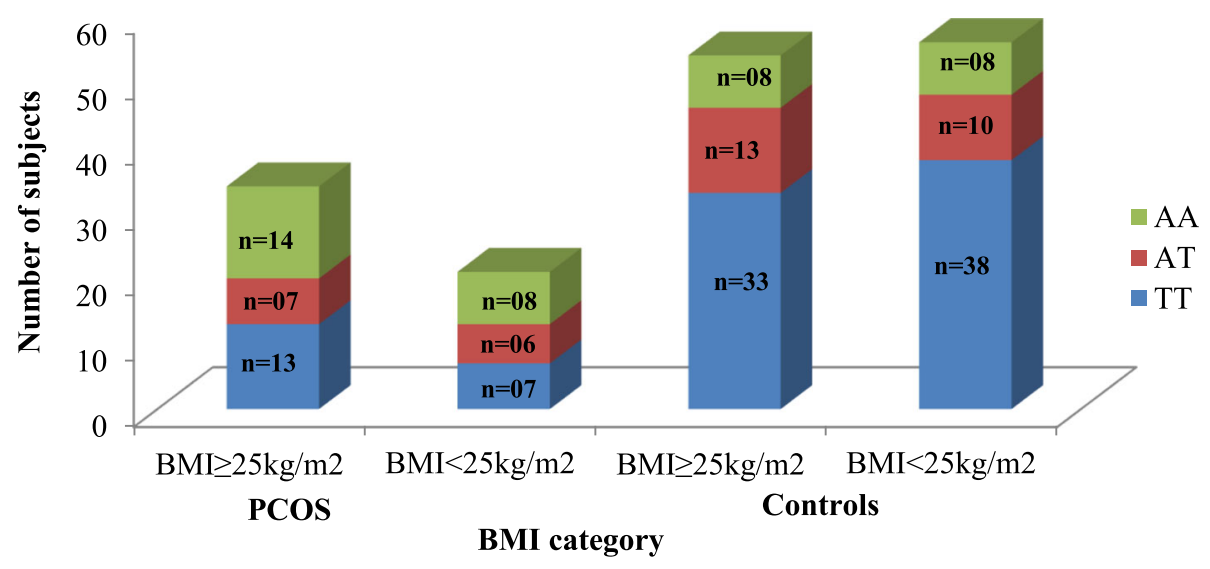

$\mathrm{n}=$ number of subjects

Fig. 2 Association between FTO genotypes and BMI in cases and controls

adjusted for confounders (Table 4). Nevertheless, we found that subjects with the FTO gene mutant alleles (AT and AA) had higher serum kisspeptin levels when compared to subjects with the normal allele $(p>0.05)$ (Fig. 1). The basis for an association of FTO gene polymorphism with increased serum kisspeptin levels is ill understood. However, association between FTO gene rs9930609 polymorphism and serum leptin levels has been investigated by several groups. Rutters et al. found FTO A allele to be associated with higher BMI and leptin levels at the age of 12 , with the association being stronger at the age of 17 [44]. Magno et al. showed that those with the AA genotype had higher values of leptin than those with TT and AT [45]. Yet others have reported the expression of Kiss1 gene (gene that produces kisspeptin) may be induced by leptin [46, 47]. Smith et al., 2006 concluded Kiss1 neurons are direct targets for regulation by leptin and suggested that the reproductive deficits associated with leptindeficient states may be attributable, in part, to diminished expression of the Kiss1 gene [48]. Therefore, we propose that the FTO gene polymorphism exerts an effect on the Kiss1 gene (that produces kisspeptin) through leptin, which leads to increased serum kisspeptin levels. Hence, further evaluation of any association between FTO gene variant and kisspeptins level is warranted. Such an approach to investigating the Kiss-1 system and associated biochemical pathways may help define therapeutic interventions that could target the reproductive consequences of PCOS.

Recent studies have examined the relationship of the FTO gene with other PCOS-associated-phenotypes, including obesity, glucose intolerance, and insulin resistance

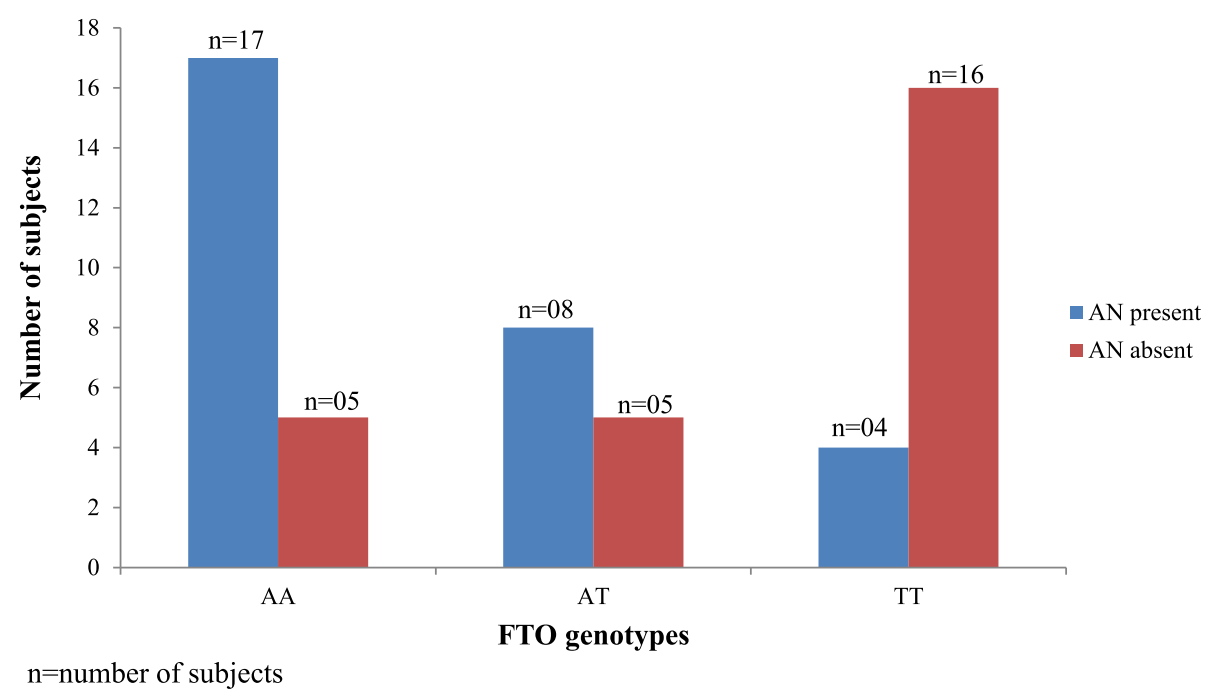

Fig. 3 Association between FTO genotypes and Acanthosis nigricans (AN) in PCOS subjects 
$[23,49]$. However, the association between the FTO gene and hyperandrogenemia remains equivocal. In a study of women from a UK population, no relationship between FTO genotype and androgen levels was observed [5]. Moreover, in a Polish population, there was no difference in testosterone, SHBG, and free androgen index values according to genotype [49]. However, a study of 288 European women with PCOS found the rs9939609 variant of the FTO gene to be associated with hyperandrogenemia [11]. Our study clearly demonstrates, using forward LR analysis, that the rs9939609 variant of the FTO gene is significantly associated with the $\mathrm{mFG}$ score for hirsutism (OR= $1.1,95 \% \mathrm{CI}=1.02-1.23, p<0.05)$ and serum testosterone levels $(\mathrm{OR}=1.1,95 \% \mathrm{CI}=1.02-1.29, p<0.05)$ that remained significant after controlling for confounders (Table 3). Hence, we propose that the FTO gene rs9939609 variant is indeed associated with hyperandrogenemia among Sri Lankan women with the well characterized phenotype of PCOS that manifests from adolescence. However, further studies in larger samples is required to confirm our findings.

This research being clinically based led to some inevitable drawbacks. These drawbacks were deviations from the original design, viz. in recruitment of subjects and data collection. The cases and control were not strictly age matched, where the mean age of controls is higher than that of the affected cohort of women with PCOS. Although this may have been due to chance, it is unlikely to have confounded the calculated risk, as age is usually not associated as a confounder of genetic testing. The explanation for the marginally older cohort of controls is that the volunteer women were selected from a single large work setting; where the controls required to be confirmed as to have regular cycles over a long period of time extending to their early adult life and had even achieved fertility; all of which clearly ensured the non-inclusion of the milder phenotype of PCOS into the control group.

Furthermore, due to the limitation of funding, LH, FSH hormones levels and thyroid testing were not determined in the control subjects. In addition, AMH level was not measured in neither cases nor controls. Hence the gonadotropin, thyroid hormones, AMH and their association with genetic polymorphisms could not be compared between cases and control subjects.

Complete data sets of the routine clinic based metabolic parameters such as lipid profile, liver enzymes and uric acid were not accessible from clinic notes in all women. Tracing through the current hospital laboratory management systems proved unsuccessful in some. Hence the association of the clinical manifestation of the metabolic syndrome with the genetic polymorphisms of PCOS could not be compared between cases and controls.

\section{Conclusion}

We conclude that the rs9939609 variant of FTO gene is significantly associated with hyperandrogenemia, acanthosis nigricans and the BMI among young Sri Lankan women with the well characterized phenotype manifesting from adolescence. Meanwhile serum kisspeptin levels have no significant association with the FTO genotypes when adjusted for confounders.

\section{Abbreviations \\ AIC: Akaike information criteria; $\mathrm{AMH}$ : Anti mullerian hormone; \\ AN: Acanthosis nigricans; BIC: Bayesian information criteria; BMl: Body mass index; Cl: Confidence interval; FSH: Follicle stimulating hormone; \\ FSHB: Follicle stimulating hormone beta subunit; FSHR: Follicle stimulating hormone receptor; FTO: Fat mass and obesity associated gene; \\ $\mathrm{GnRH}$ : Gonadotropin releasing hormone; HPG: Hypothalamic pituitary axis; INSR: Insulin receptor; IR: Insulin resistance; LH: Luteinizing hormone; LHB: Luteinizing hormone beta subunit; LHCGR: Luteinizing hormone/ choriogonadotropin receptor; LR: Logistic regression; $\mathrm{mFG}$ : Modified Ferriman-Gallwey; OR: Odd ratio; PCOS: Polycystic ovary syndrome; SHBG: Sex hormone binding globulin; SNP: Single nucleotide polymorphism}

\section{Acknowledgements}

We thank all the staff of the Professorial Obstetrics and Gynaecology Department and Professorial Unit of De Soysa Hospital for Women, Colombo for their ready assistance and support with ultrasound scanning, all staff of the Reproductive Biology and Endocrinology Laboratory, at the Department of Obstetrics and Gynecology, Faculty of Medicine and the patients and their families for their wonderful cooperation. We also thank the staff of Bank of Ceylon, Head office, Colombo for their voluntary participation for the study. We specially thank Dr. Anoma Senanayake for her excellent support during the ultrasound examinations. We also thank Dr. Sumudu Jayasinghe and Dr. Dakshila Galappathi for their excellent support in coordinating the patient evaluation and sample collections. A part of this study was presented the 10th International Conference on Food, Ecology, Biological and Medical Sciences (FEBM-17) in 2017 (http://dirpub.org/images/proceedings_pdf/ DIR1217205.pdf).

\section{Authors' contributions}

UB contributed to acquisition of data, analysis and interpretation of data and manuscript drafting. SW contributed to study design, execution, acquisition, analysis and interpretation of data, manuscript drafting and critical discussion. VC contributed to study design, execution and critical discussion. CA contributed to analysis and interpretation of data, manuscript drafting and critical discussion CW contributed to study design, execution, acquisition, analysis and interpretation of data, manuscript drafting and critical discussion. All authors read and approved the final manuscript.

\section{Funding}

This study was funded by National Research Council (Grant No. 15-149) of Sri Lanka and University of Colombo (Grant no: AP/3/2/2017/SG/09).

\section{Availability of data and materials}

The datasets generated and/or analyzed during the current study are available in the Figshare repository (https://figshare.com/articles/Complete_ Gene_results_BMC_sav/11637264).

\section{Ethics approval and consent to participate}

This study was approved by the Ethics Review Committee (EC-14-044), Faculty of Medicine, University of Colombo, Sri Lanka. Written informed consent was obtained from all participants.

Consent for publication

Not applicable.

Competing interests

The authors declare that they have no competing interests. 


\section{Author details}

'Department of Obstetrics and Gynecology, Faculty of Medicine, University of Colombo, PO Box 271, Kynsey Road, Colombo 08, Sri Lanka. ${ }^{2}$ Department of Biochemistry and Molecular Biology, Faculty of Medicine, University of Colombo, PO Box 271, Kynsey Road, Colombo 08, Sri Lanka. ${ }^{3}$ Department of Chemistry, Faculty of Science, University of Colombo, Colombo 07, Sri Lanka. ${ }^{4}$ Department of Community Medicine, Faculty of Medicine, University of Colombo, PO Box 271, Kynsey Road, Colombo 08, Sri Lanka.

Received: 13 June 2019 Accepted: 23 January 2020

\section{Published online: 12 February 2020}

\section{References}

1. Balen AH, Conway GS, Kaltsas G, Techatrasak K, Manning PJ, West C, Jacobs HS. Polycystic ovary syndrome: the spectrum of the disorder in 1741 patients. Hum Reprod. 1995;10:2107-11.

2. Wijeyaratne $\mathrm{CN}$, Udayangani $\mathrm{SAD}$, Balen $\mathrm{AH}$. Ethnic-specific polycystic ovary syndrome: epidemiology, significance and implications. Expert Rev Endocrinol Metab. 2013;8(1):71-9.

3. Studen KB, Pfeifer M. Cardiometabolic risk in polycystic ovary syndrome. Endocr Connect. 2018;7(7):R238-51.

4. Apridonidze T, Essah PA, lurno MJ, Nestler JE. Prevalence and characteristics of the metabolic syndrome in women with polycystic ovary syndrome. J Clin Endocrinol Metab. 2005;90:1929-35.

5. Barber TM, Bennett AJ, Groves CJ, Sovio U, Ruokonen A, Martikainen H, Pouta A, Hartikainen AL, Elliott P, Lindgren CM, Freathy RM, Koch K, Ouwehand WH, Karpe F, Conway GS, Wass JA, Järvelin MR, Franks S, McCarthy MI. Association of variants in the fat mass and obesity associated (FTO) gene with polycystic ovary syndrome. Diabetologia. 2008;51(7):1153-8.

6. Alexander CJ, Tangchitnob E, Lepor NE. Polycystic ovary syndrome: a major unrecognized cardiovascular risk factor in women. Rev Cardiovasc Med. 2009;10:83-90

7. Diamanti-Kandarakis E, Piperi C, Spina J, Argyrakopoulou G, Papanastasiou L, Bergiele A, Panidis D. Polycystic ovary syndrome: the influence of environmental and genetic factors. Hormones (Athens) Rev. 2006;5(1):17-34.

8. Diamanti-Kandarakis E, Christakou C, Kandarakis H, Alexandraki KI. Early onset adiposity: a pathway to polycystic ovary syndrome in adolescents? Hormones (Athens). 2007;6(3):210-7.

9. Diamanti-Kandarakis E, Christakou C, Palioura E, Kandaraki E, Livadas S. Does polycystic ovary syndrome start in childhood? Pediatr Endocrinol Rev. 2008; 5(4):904-11.

10. Frayling TM, Timpson NJ, Weedon MN, Zeggini E, Freathy RM, Lindgren CM, Perry JR, Elliott KS, Lango H, Rayner NW, Shields B, Harries LW, Barrett JC, Ellard S, Groves CJ, Knight B, Patch AM, Ness AR, Ebrahim S, Lawlor DA, Ring SM, Ben-Shlomo Y, Jarvelin MR, Sovio U, Bennett AJ, Melzer D, Ferrucci L, Loos RJ, Barroso I, Wareham NJ, Karpe F, Owen KR, Cardon LR, Walker M, Hitman GA, Palmer CN, Doney AS, Morris AD, Smith GD, Hattersley AT, McCarthy Ml. A common variant in the FTO gene is associated with body mass index and predisposes to childhood and adult obesity. Science. 2007; 316(5826):889-94

11. Wehr E, Schweighofer N, Moller R, Giuliani A, Pieber TR, Obermayer-Pietsch B. Association of FTO gene with hyperandrogenemia and metabolic parameters in women with polycystic ovary syndrome. Metabolism. 2010;59:575-80.

12. De Luis DA, Aller R, Conde R, Izaola O, De La Fuente B, Sagrado MG. Relation of the rs9939609 gene variant in fto with metabolic syndrome in obese female patients. J Diabetes Complicat. 2013;27(4):346-50.

13. Ohtaki T, Shintani $Y$, Honda S, Matsumoto H, Hori A, Kanehashi K, Terao $Y$, Kumano S, Takatsu Y, Masuda Y, Ishibashi Y, Watanabe T, Asada M, Yamada T, Suenaga M, Kitada C, Usuki S, Kurokawa T, Onda H, Nishimura O, Fujino M. Metastasis suppressor gene KiSS-1 encodes peptide ligand of a Gprotein-coupled receptor. Nature. 2001;411(6837):613-7.

14. Ojeda SR, Urbanski HF, Ahmed CE. The onset of female puberty: studies in the rat. Recent Prog Horm Res. 1986;42:385-442.

15. Luan X, Zhou Y, Wang W, Yu H, Li P, Gan X, Wei D, Xiao J. Association study of the polymorphisms in the KISS1 gene with central precocious puberty in Chinese girls. Eur J Endocrinol. 2007;157(1):113-8.

16. Levine JE. In: Encyclopedia of hormones. Henry H, Norman A, editors. Gonadotropin-releasing hormone (GnRH); 2003. p. 157-65.

17. Sam S. Obesity and polycystic ovary syndrome. Obes Manag. 2007;3(2):69-73.

18. Barber TM, Franks $S$. The link between polycystic ovary syndrome and both type 1 and type 2 diabetes mellitus. Women Health. 2012;8(2):147-54.
19. Yan Q, Hong J, Gu W, Zhang Y, Liu Q, Su Y, Zhang Y, Li X, Cui B, Ning G. Association of the common rs9939609 variant of FTO gene with polycystic ovary syndrome in Chinese women. Endocrine. 2009;36(3):377-82.

20. Osman HG, El-Refaeey AAA, El-Sokkary AMA, El-Sokkary MMA, El-Saeed RA. A study on fat mass and obesity associated (FTO) gene rs9939609 variant in Egyptian women with polycystic ovarian syndrome. Aust J Basic Appl Sci. 2014;8(13):98-104

21. Al-Tu'ma FJ, HadiFarhan N, Al-Safi WG. Association between fat mass and obesity Geners9939609 polymorphism with PCOS women in Iraqi population. ljppr Human. 2015;5(1):62-72.

22. Mehta J, Kamdar V, Dumesic D. Phenotypic expression of polycystic ovary syndrome in south Asian women. Obstet Gynecol Surv. 2013;68(3):228-34.

23. Attaoua R, Ait El Mkadem S, Radian S, Fica S, Hanzu F, Albu A, Gheorghiu M, Coculescu M, Grigorescu F. FTO gene associates to metabolic syndrome in women with polycystic ovary syndrome. Biochem Biophys Res Commun. 2008;373:230-4

24. Song DK, Lee $H$, Oh JY, Hong YS, Sung YA. FTO gene variants are associated with PCOS susceptibility and hyperandrogenemia in young Korean women. Diabetes Metab J. 2014;38(4):302-10.

25. Rotterdam ESHRE/ASRM-Sponsored PCOS Consensus Workshop Group. Revised 2003 consensus on diagnostic criteria and long-term health risks related to polycystic ovary syndrome. Fertil Steril. 2004;81:19-25.

26. Schlesselman J. Case-control studies: design, conduct, analysis, vol. 354 New York: Oxford University Press; 1982.

27. Umayal B, Jayakody SN, Chandrasekharan NV, Wijesundera WS, Wijeyaratne CN. Polycystic ovary syndrome (PCOS) and kisspeptin - a Sri Lankan study. J Postgrad Med. 2019;65(1):18-23.

28. Branavan U, Muneeswaran $\mathrm{K}$, Wijesundera S, Jayakody S, Chandrasekharan V, Wijeyaratne C. Identification of selected genetic polymorphisms in polycystic ovary syndrome in Sri Lankan women using low cost genotyping techniques. PLoS One. 2018;13(12):e0209830 https://doi.org/10.1371/journal. pone.0209830.

29. Branavan U, Muneeswaran K, Wijesundera WSS, Senanayake A, Chandrasekharan NV, Wijeyaratne CN. Association of Kiss1 and GPR54 gene polymorphisms with polycystic ovary syndrome among Sri Lankan women. Biomed Res Int. 2019; https://doi.org/10.1155/2019/6235680.

30. Valkenburg O, Uitterlinden AG, Piersma D, Hofman A, Themmen AP, de Jong FH, Fauser BC, Laven JS. Genetic polymorphisms of GnRH and gonadotrophic hormone receptors affect the phenotype of polycystic ovary syndrome. Hum Reprod. 2009;24:2014-22.

31. Chen ZJ, Zhao H, He L, Shi Y, Qin Y, Shi Y, Li Z, You L, Zhao J, Liu J, Liang X, Zhao X, Zhao J, Sun Y, Zhang B, Jiang H, Zhao D, Bian Y, Gao X, Geng L, Li Y, Zhu D, Sun X, Xu JE, Hao C, Ren CE, Zhang Y, Chen S, Zhang W, Yang A, Yan J, Li Y, Ma J, Zhao Y. Genome-wide association study identifies susceptibility loci for polycystic ovary syndrome on chromosome 2p16.3, 2p21 and 9q33.3. Nat Genet. 2011:43:55-9.

32. Shi Y, Zhao H, Shi Y, Cao Y, Yang D, Li Z, Zhang B, Liang X, Li T, Chen J, Shen J, Zhao J, You L, Gao X, Zhu D, Zhao X, Yan Y, Qin Y, Li W, Yan J, Wang Q, Zhao J, Geng L, Ma J, Zhao Y, He G, Zhang A, Zou S, Yang A, Liu J, Li W, Li B, Wan C, Qin Y, Shi J, Yang J, Jiang H, Xu JE, Qi X, Sun Y, Zhang Y, Hao C, Ju X, Zhao D, Ren CE, Li X, Zhang W, Zhang Y, Zhang J, Wu D, Zhang C, He L, Chen ZJ. Genome-wide association study identifies eight new risk loci for polycystic ovary syndrome. Nat Genet. 2012;44:1020-5.

33. Boteju WMM, Karunarathna GDKN, Udayangani SAD, Silva KGH, Wijeyaratne CN. Markers of hyperandrogenism in south Asians with polycystic ovary syndrome. Sri Lanka J Diabetes Endocrinol Metab. 2014;4:3-8.

34. Balasooriya S, Fernando MA. Seasonal variation of menarche in Sri Lanka. Ceylon Med J. 1988;33:105-9.

35. Jakubowski L. Genetic aspects of polycystic ovary syndrome. Endokrynol Pol. 2005;56(3):285-93.

36. Legro RS, Kunselman AR, Dodson WC, Dunaif A. Prevalence and predictors of risk for type 2 diabetes mellitus and impaired glucose tolerance in polycystic ovary syndrome: a prospective, controlled study in 254 affected women. J Clin Endocrinol Metab. 1999;84(1):165-9.

37. Barber TM, McCarthy MI, Wass JA, Franks S. Obesity and polycystic ovary syndrome. Clin Endocrinol. 2006;65(2):137-45.

38. Li T, Wu K, You L, Xing $X$, Wang $P$, Cui L, Liu H, Cui Y, Bian Y, Ning Y, Zhao $\mathrm{H}$, Tang R, Chen ZJ. Common variant rs9939609 in gene FTO confers risk to polycystic ovary syndrome. PLoS One. 2013;8:e66250.

39. Tan S, Scherag A, Janssen OE, Hahn S, Lahner H, Dietz T, Scherag S, Grallert H, Vogel Cl, Kimmig R, Illig T, Mann K, Hebebrand J, Hinney A. Large effects 
on body mass index and insulin resistance of fat mass and obesity associated gene (FTO) variants in patients with polycystic ovary syndrome (PCOS). BMC Med Genet. 2010;11:12.

40. Liu AL, Xie HJ, Xie HY, Liu J, Yin J, Hu JS, Peng CY. Association between fat mass and obesity associated (FTO) gene rs9939609 A/T polymorphism and polycystic ovary syndrome: a systematic review and meta-analysis. BMC Med Genet. 2017;18(1):89.

41. Ewens KG, Jones MR, Ankener W, Stewart DR, Urbanek M, Dunaif A, Legro RS, Chua A, Azziz R, Spielman RS, Goodarzi MO, Strauss JF 3rd. Type 2 diabetes susceptibility single-nucleotide polymorphisms are not associated with polycystic ovary syndrome. Fertil Steril. 2011;95(8):2538-41.

42. Russell MA, Morgan NG. Conditional expression of the FTO gene product in rat INS-1 cells reveals its rapid turnover and a role in the profile of glucoseinduced insulin secretion. Clin Sci (Lond). 2011;120:403-13.

43. Wijeyaratne CN, Seneviratne Rde A, Dahanayake S, Kumarapeli V, Palipane E, Kuruppu N, et al. Phenotype and metabolic profile of south Asian women with polycystic ovary syndrome (PCOS): results of a large database from a specialist endocrine clinic. Hum Reprod. 2011;26(1):202-13.

44. Rutters F, Nieuwenhuizen AG, Bouwman F, Mariman E, Westerterp-Plantenga MS. Associations between a single nucleotide polymorphism of the FTO gene (rs9939609) and obesity-related characteristics over time during puberty in a Dutch children cohort. J Clin Endocrinol Metab. 2011;96:E939-42.

45. Magno FCCM, Guaraná HC, Fonseca ACP, Cabello GMK, Carneiro JRI, Pedrosa AP, Ximenes AC, Rosado EL. Influence of FTO rs9939609 polymorphism on appetite, ghrelin, leptin, IL6, TNFa levels, and food intake of women with morbid obesity. Diabetes Metab Syndr Obes. 2018:11:199-207.

46. Oakley AE, Clifton DK, Steiner RA. Kisspeptin signaling in the brain. Endocr Rev. 2009;30(6):713-43.

47. Pankov YA. Kisspeptin and leptin in the regulation of fertility. Mol Biol (Mosk). 2015:49(5):707-15.

48. Smith JT, Acohido BV, Clifton DK, Steiner RA. KiSS-1 neurones are direct targets for leptin in the ob/ob mouse. J Neuroendocrinol. 2006;18(4):298-303.

49. Kowalska I, Malecki MT, Straczkowski M, Skupien J, Karczewska-Kupczewska M, Nikolajuk A, Szopa M, Adamska A, Wawrusiewicz-Kurylonek N, Wołczynski S, Sieradzki J, Gorska M. The FTO gene modifies weight, fat mass and insulin sensitivity in women with polycystic ovary syndrome, where its role may be larger than in other phenotypes. Diabetes Metab. 2009;35:328-31.

\section{Publisher's Note}

Springer Nature remains neutral with regard to jurisdictional claims in published maps and institutional affiliations.

Ready to submit your research? Choose BMC and benefit from:

- fast, convenient online submission

- thorough peer review by experienced researchers in your field

- rapid publication on acceptance

- support for research data, including large and complex data types

- gold Open Access which fosters wider collaboration and increased citations

- maximum visibility for your research: over $100 \mathrm{M}$ website views per year

At BMC, research is always in progress.

Learn more biomedcentral.com/submissions 